\title{
Networked Idiots:
}

\section{Affective Economies and Neoliberal Subjectivity in Russian Viral Video}

\begin{abstract}
Idiot is usually a term of derision. In this article, we reconsider the common meaning as designating a stupid person and return to an earlier etymology as signifying a private and independent individual. In ancient Greece, being idiotic meant engaging in the contemplative process of becoming an individual. At times, this pursuit of individuation differentiated such individuals as their acts occurred in public and were seen as absurd, out-of-the-ordinary, and, frankly, idiotic, as most now know the term. With the widespread use of social media and digital video, these once private or semi-public acts of individuation often become explicitly public acts for others to see, critique, and mimic. Social media has made it possible for these explorations of self to circulate where their emotional intensities resonate with or are rejected by viewers, are captured for profit by media corporations, and leveraged by their producers into media careers. This article describes this affective economy of idiotic videos in the Russian language and how the history of one internet video illustrates the circulation, capture, and self-capitalization attendant with neoliberalism.
\end{abstract}

\section{Key Terms}

video, affect, capture, neoliberalism, idiot, Russia 


\section{Networked Idiots}

Calling something idiotic is incendiary. In common use, the term is synonymous with being stupid or unskilled. In this article, we take a different approach to "idiots" by returning to its original ancient Greek etymology as describing unique, private citizens (Curtis, 2013). The idiot is an independently minded individual whose naive confidence enables explorations of the socially liminal, without concerns to "save face" by avoiding embarrassment (Goffman, 1955). Recently, media scholars have redeemed the term and linked it to the circulation of emotional intensities in online affective economies (Hands, 2014; Goriunova, 2013; Horeck and Kendall, 2014). From this theoretical perspective, we analyze one Russian-language internet video and follow what happens to its producer as he becomes famous and the video as it enters into the networked public sphere. In this article, we link theories of affect with an example of idiot video to describe economic capture and neoliberal subjectification.

Here we describe the theory of the idiot specific to the Russian context, show how the idiot links to theories of affect, and elaborate upon the relationships between digital media, and in particular internet video, and affect. Before describing our methods, we connect the theory of affect, and the public idiot to the concept to neoliberal subjectivity. Our case study of Victor Goncharenko's Ide video follows to illustrate how affect circulates across and is captured by media platforms. In the process, Goncharenko transforms from a reluctant, private citizen to a public neoliberal subject.

Idiot has a specific meaning in the Russian context. The "idiot” in Russian author Fyodor Dostoevsky’s The Idiot (1869), Prince Myshkin, embodies kindness, honesty, and unselfishness. This character is humble and gentle, and alien to arrogance and cynicism. 
His straightforward way of thinking and acting bewilders society. Prince Myshkin, unlike others, is not ashamed of being himself even if he looks odd: "It is not such a very dreadful circumstance that we are odd people, is it? For we really are odd, you know — careless, reckless, easily wearied of anything...” he states (Dostoevsky 1869). In this recognition that being odd is subjectively acceptable, Dostoevsky's character expresses a fundamental truth of the idiot: "No one can begin by being perfect — there is much one cannot understand in life at first. In order to attain to perfection, one must begin by failing to understand much” (ibid.). In embracing difference and the individualized path of selfawareness, the idiot gains subjective freedom from a conformist hegemonic society.

In Ancient Greece, idiotai had both denotative and connotative (and pejorative) meanings. Idiotai lacked expertise and education (agramattoi) and were unprepared or unwilling to participate in civic life (Ober 1991). The early Christians, who were not engaged in pagan intellectualism, elevated private spiritual life above public political life, and embraced being called idiotai (Eshelman 2012). Like Dostoyevsky’s Mishkin, they were holy fools. This appreciation of the holy fool comes to Russia from Greece via the Greek Orthodox tradition. In Soviet-times one was expected to be educated, cultured, and disinterested in public economic ambition. Inversions of this ideal type, the carnivalesque and its celebration of eccentricity, ritual reversals, misalliances, jolly frivolity, grotesque bodies, sacrilege — and holy fools and their political agnosticism--were revered (Bahktin 1941). This changed in the post-Soviet times. One need be serious, sophisticated, and politically mindful—as well as engaged in public economic ambitions. The carnivalesque retreated and with it the holy fool. Social media provided a platform and public return of idiotai-with a neoliberal economic twist that emphasizes the market. 
The "idiot" is a figure who seeks the truth through the absurd by becoming a craftsman (Deleuze and Guattari, 1999, Deleuze 2008). Deleuze and Guattari claim that (1994: 62) "[t]he Old idiot wanted truth, but the new idiot wants to turn the absurd into the highest power of thought--in other words, to create” This new media idiot appears when "Descartes goes mad in Russia” (ibid.). Participatory affordances of the internet empower new idiotic craftsmanship by enabling many with the means of media production to publicly perform idiosyncratic behavior and explore social liminality. Russian new media scholar Olga Goriunova (2013) articulates the concept of "new media idiocy” as a new kind of idiocy performed in digital networks. Many different kinds of digital cultural objects circulate in online networks, such as memes and viral videos, which are examples of aesthetic expression that "have performance of idiocy at their core” (Goriunova, 2013: 223). Drawing on Deleuze’s interpretation of idiocy as a mode of living, she describes "new media idiocy" in terms of a "crafted, participatory performance [and] as a mode of living with technical networks” (Goriunova, 2013: 224). Digital networks enable the processes of individuation, which previously only unfolded privately, to take place in public. While we deploy the analytic distinctions "public" and "private" throughout this article, we understand these not as binaries but as variables existing on a connected continuum (Papacharissi, 2010). Networks facilitate the movement along this spectrum from less privacy to more publicity. With greater publicity, comes an increase in the potential for capitalist capture.

\section{Affective Economies of Internet Video}


Elaborating on the work of Douglas Hofstadter (2000), develops the concept of "digital entwined feedback loops" to describe the circulation of affect or the "building of the tendencies toward affinity and empathy” within "idiot collectives” (2014: 241-242). Loops, circulation, and crafting make us consider Williams's classic definition of technologies of affect as "structures of feelings" (1977). Affect is associated with potential bodily responses that augment or diminish a body's capacity to act or to connect with others (Clough, 2007: 1-2). Gregg and Seigworth define affect as those vital visceral forces that can serve to "drive us toward movement, toward thought and extension", or, more generally, "to act and be acted upon” (2010: 1). Hansen (2004) considers affect a key aspect in the process of engagement with digital information and emphasizes that the body's capacity for affect determines how people select perceptions from the world (Featherstone, 2010). Similarly, Lazzarato treats electronic and digital technologies as "motors of affective energy" (2007: 115). New information technologies provide great possibilities for the generation of affective intensities to be transmitted and experienced by other users (Raum 2012: 166-167). This way, digital media "enable individuals to transmit or move a sensory experience of self-presence "elsewhere” across virtual space" (Hillis, 2009: 2). Following this, one might conclude that it is not only the affective object that matters but also the way it is communicated and perceived in online communities. As Lovink said (2011: 138), the social is not "redundant noise," in fact, it is the materialized structures of feelings connecting people, technologies, and emotional events.

"To study online video" according to Geert Lovink, is to investigate "affect" (2011: 138). However, affect is difficult to engineer. Affective viral videos emerge from 
the most improbable and accidental of spaces. Classic viral videos such as The Star Wars Kid, the Numa Numa dancer, and David After the Dentist, did not intend to go viral. Comment [AF1]: Cite Much like the video we explore in this article, these early viral videos were private acts made public because of their emotional intensity. The sharing, posting and re-posting of affective objects and statements determines the capacity of emotions to move within and through online networks (Kuntsman, 2012). The movement of emotions has been explored by Sara Ahmed (2004) who argues that emotions are not simply generated from "within"; rather they gain strength from the interaction and connectedness of people (2004a). She introduces the concept of "affective economy" as an economy where emotions are not just experienced, but constantly being accumulated and exchanged between people. As Ahmed argues, “emotions work as a form of capital: affect does not reside positively in the sign or commodity, but is produced as an effect of its circulation” (2004b: 45). YouTube users' comments, remixes, for instance contribute to the affective economy of idiot performances. We prefer affective economy to collective for the same reason we prefer the term network over collective. Economy, like network, designates circulation without affinity or "cause” (Lovink, 2011). Thus, what scholars of affect in new media point out, is the capacity of emotions to be produced, circulated, and “captured” in online economies.

Thus, it is instructive to consider affective economies in light of Deleuze's concept of the "double-movement of liberation and capture" (1972). While affective economies offer opportunities for the liberation of activist visibility, they also provide information corporations opportunities to capture social capital in the form of affective intensities. Chow says captivation "is semantically suspended between an aggressive 
move and an affective state, and carries within it the force of the trap in both active and reactive senses” (Chow, 2012: 48, in Berry, 2014). In this way, affectual data is captured by information corporations capable of situating themselves at key junctures in the affective economy.

Affect economies rely upon the management of emotion in ways not dissimilar to ways people are hailed to comport themselves within neoliberalism. Marwick explores how neoliberalism unfolds in the business of social media "which idealize[s] and reward[s] a particular persona: highly visible, entrepreneurial, and self-configured to be watched and consumed by others” (2013: 13). Drawing on Foucault's concept of "technologies of the self”, defined as a specific matrix of practical reason through which people learn to transform themselves in order to achieve a desired state (1988: 18), Marwick explains how social media make people regulate and alter their behavior along neoliberal principles. Online networks help individuals obtain a particular status, reputation, and popularity by using self-presentation strategies such as life-streaming, self-branding, and micro-celebrity (Marwick, 2013). Thus, social media teaches users how to prosper in consumer society "where status is predicated on the cultural logic of celebrity, according to which the highest value is given to mediation, visibility, and attention” (Marwick, 2013: 14). These ideas have implications to YouTube users whose idiot performances have brought great public attention and recognizability within online communities. If they were not intending to become microcelebrities, but gain accidental notoriety because of the shareability of their content, they may soon be hailed to comport themselves in a neoliberal manner in order to reap the personal and financial rewards of being a central node in the affective economy. 
Our research into Russian YouTube video producers extends and diverges from these concepts of idiotism, affect, capture, neoliberal subjectivity, and feedback loops. Instead of being forced into privatization our subjects are encouraged to make profit as well as the dictates of neoliberal self-managerialism to go public. The self-governing polis of private citizens gives way to the agora of public self-commercialization. Our example is closer to Lovink's (2011) concept of "networks without a cause," than Hands's idiot collective, which while consisting of self-managing individuals still shares a collective energy. For this reason, we use the term networked idiots rather than idiot collectives. The individuals entwined in digital feedback loops have no concept of collectivity.

\section{Methodology}

Below, we trace the circuitry of one video as it transects various media platforms, institutions, and human minds. On the assumption that there is a feedback loop connecting producers and viewers, we applied a multi-dimensional methodology to explore the patterns of engagement inclusive of both producers and audience. Using qualitative methods, we systematically explore the affective economy of Russian idiot videos. Firstly, we collected data from YouTube about popular Russian videos commonly considered by users to be "idiotic". We strove to find out how the clips were made, in what circumstances, how they appeared on YouTube, and what the producers' and viewers' attitudes were to these videos. For these purposes, we watched the videos, looked at various online press releases, TV shows records, and social media posts, 
including those made by the authors of the videos. We explored different forms of the videos' derivatives such as parodies, remixes and mashups, as well as different kinds of appropriation of the video by various actors, including advertisement parties and DJs. From this research, we selected one example to illustrate our interpretations. In order to examine the opinions of viewers in relation to the chosen video, we conducted an analysis of YouTube comments on this video. We read all the comments posted by YouTube users on the video (n805) and selected the most indicative examples for supporting our research arguments. Along with that, we conducted an interview with the producer of the video to learn more about his personal incentives. Below, we trace the transmedia trajectory of this video as it remixed in online videos, music, and television shows. This methodology enables us to emphasize the circulation, feedback, and capture of affect.

\section{"Ide - The Fish of My Dreams"}

In the autumn of 2011, a video emerged on Russian social media and video sites featuring a solitary man on a sunny lake holding a big fish and gleefully exclaiming: "Here it is, the fish of my dreams!” followed by a boisterous "Ya-a-az! Ya-a-a-a-z! Ya-aa-a-a-zz!!!” (that means Ide in Russian, $Я_{3 b}$ ) “What an idiot!” was indicative of the tenor of many comments. As happens, virality and then profitable celebrity for the fisherman

followed. We analyze the trajectory of this video because it is indicative of the path followed by many viral videos both in Russia and elsewhere. Idiot videos might not display videographical skill or ingenuity; their virality depends upon reactions that evoke 
an urge to respond, reject, imitate, and share. The economies of idiot videos rely first on affect and later on instrumental self-regulation.

This emotional video evoked a large number of responses from Internet users. It should be mentioned that such expressions as "idiotic behavior", "idiotic enthusiasm”, "idiotic laughter", and "idiotic scream" are quite frequent in the discourse of YouTube viewers of Ide. However, the tone of such phrases varies extremely. Many viewers express joy and delight from watching the clip, which is discussed in terms of "funny", "amusing”, "laughable", "humorous", "positive”. From analyzing the comments, it might be assumed that the nature of these joyful emotions might be different. As some of the users point out, they are honestly glad for the fisherman whose behavior and reaction are perceived as "pure emotions", "genuine pleasure", "sincere joy", and "true human happiness". At the same time, a great number of viewers emphasize the "absurdity" and "ridiculousness" of the scene that makes them laugh.

For many viewers the video evokes an urge to cry the same way as the performer. Viewers write: “I want to scream myself” (couldchangeme, YouTube, 2012; Yana54038, YouTube, 2012); “now all of my friends are yelling 'Yaaaazz” (Evgeny Goncharov, YouTube, 2012), "Everybody is crying 'YAAAAAAAAAZ”' (Gavarun, YouTube, 2014). Many comments merely consist of the expression "Yaaaazz" written in different ways with exclamation marks and emoticons. A large part of the audience is excited about the "shocking laughter" of the fisherman and his strange phrase at the end. Some users give their interpretations about the term's meaning, in which the most popular is that it is swearing in the Armenian language. While some viewers find the video humorous and interesting, others argue that it is "stupid", "unfunny", and 
"pathetic". There are also many aggressive comments with abusive language towards the performer. These users often state that this performance evokes disgust. One viewer writes the following: "He has just exposed himself as a moron...His screaming enrages me!” (Killer-Sergey-3, YouTube, 2013). What can be understood from all of these comments is how the video generates bodily reactions. An affective economy is constituted by the "digital entwined feedback loops” (Hands, 2014) from producers, reactive audiences, and digital networks themselves.

Many viewers express a genuine surprise at the large number of views. In this regard, one of the users observes: "Yes, the Internet loves freaks" (Alleksei27, YouTube, 2013). This simple point is important as it explains why "idiotic" video travels so well across various media platforms. The Internet mania with idiotic performances can be revealed through the virality of such videos as the coke and mentos experiments, the cinnamon challenges, spilling milk at a Walmart or other public spaces, and Nekknomination. This phenomenon has a prehistory in popular TV shows such as “America’s Funniest Home Videos” and the Russian analog “Director Himself,” as well as more extreme versions such as “Jackass”, an American reality series featuring people performing various pranks and stunts (generally, dangerous and self-injuring). A similar Belarusian show called "Idiots" has recently launched on YouTube. This "Idiotik Show" offers videos described as “crazy tricks performed by funny guys”(YouTube, 2012). While not exclusively an internet phenomenon, these examples demonstrate the capacity of idiot videos to create robust affective economies.

Ide producer Victor Goncharenko is a former policeman who loves fishing and hunting. As he explains, he has been waiting for such a fish for twenty-five years. When 
Goncharenko was fishing that day, he suddenly realized from a hard hit on the spinning rod that a huge fish was on the line, so he started making a video on his camera. According to his words, he was so happy about catching such a big Ide fish, which is unusual for that lake, that he started screaming and laughing for joy. His incomprehensible words at the end of the video were nonsense spontaneously invented by him as an expression of his ineffable joy. A usually private act, thus, is recorded on video and made public online, circulating in an affective economy. Tracing the travel of the video, its remixes, and the career of Goncharenko, illustrate the formulation of affective economies.

Goncharenko wanted to demonstrate his haul to friends and other fisherman and asked his son to upload the video on Russian social networking website Vkontakte.ru, into the online group devoted to hunting and fishing, where he actively participates. That fact indicates lifestreaming online activity within the particular "community of interests," in Benkler's (2006) terms. Lifestreaming involves two processes: tracking personal information and broadcasting it to an audience (Marwick, 2013). The networked audience is a crucial element of lifestreaming because it provides feedback for the looping within the affective economy. Participation in social media has many benefits, including intimacy, friendship, and status (Marwick, 2013). The way people share their personal life with others in exchange for inclusion and intimacy encourages increasing publicity (Marwick, 2013: 230), which necessitates openness, visibility, attention, and spectacle (Dean, 2002). Originally, his video was intended for a semi-private group of people rather than for a wide audience. However, within a short period, the video migrated to YouTube and it gave birth to a constellation of audio and video parodies. 
YouTube is congested with numerous Russian parodies of Ide from similar videos in which people demonstrate a really big fish to ironic versions featuring people's delight about a tiny fish. There also have been a large number of caricatures such as videos of people holding different things (animals, vegetables, fruit, etc.) and shouting that this is something of "their dreams". These parodies vary in their creativity and character: from well-staged performances to simple yelling; from inoffensive jokes to mockery and trolling.

Furthermore, there has been a trend of integrating phrases from Ide in popular movies. For instance, one user replaced the original sound-track in the film "Kindergarten Cop”, with Arnold Schwarzenegger scaring children by crying "Yaaazz”! More than 1.6 million users watch a video where Goncharenko's speech in Ide is reversed so that sounds quite horrendous, as most viewers point out (YouTube, 2011). Due to the participatory affordances of networks and the digital, Goncharenko (together with some other YouTube celebrities) turns into a hero of popular cartoons, remixes, and animation films. In addition to circulation amongst commentators, the feedback loop also circulates amongst video remixers. Throughout, Ide is reformatted while residual affectations remain.

Productive audience reaction to such a video might be considered in terms of what Hardt and Negri (2000: 292) call "affective labour" which is described as work that is corporeal, concerned with "the creation and manipulation of affect" and productive of social networks. Moreover, as evident from Ide, an emotional "idiot" video becomes the source of creating other affective videos. This clearly demonstrates the wide possibilities of circulation and accumulation of emotions in the digital media environment. The 
audience's participation in the production and performance of idiocy in the Ide case varies from simply posting comments or sharing a video link to more intricate practices such as making remixes and parodies. What is interesting about parodying is that the producers embody the idiotic behavior of the video's hero themselves. This is how networked idiots develop: through joining in, responding and circulating, emboding practices of impersonation, and ironic reproduction of idiotic acts. We should not forget that this is a type of unpaid labor, economical energy captured for the financial gain of individuals who are not often the producers (Author and RS, 2012).

Ide's virality and the accidental fame of its impassioned performer can be compared to the earlier popularity of Russian Eduard Khil's video of his emotional singing, which was uploaded on YouTube and caused the emergence of the "Trololo" meme. Similarly, these Internet memes have arisen spontaneously and have been developed through multiple users' practices. Interestingly, at the heart of both performances is an exposure of joy and delight. As Goriunova, suggests, "the happy idiot is a non-dangerous, friendly idiot whose performance is discovered and greeted instantly through the networks, by the multitudes” (2013: 231). From this perspective, the joy of idiocy can be conceptualized as part of the emotional fabric of social media.

In attempts to explore what draws people to imitate and remake viral and memetic videos, Shifman (2014) suggests the following features: simple packaging, humor, and augmented participation tools. As she states, simplicity facilitates memetic responses, since simple content is easy to imitate (2014: 96). Secondly, humor augments sharing, as "people wish to amuse their friends and to be associated with wittiness", and also encourages video remaking practices that seem to be intertwined with playfulness, 
incongruity, and feelings of superiority (Shifman, 2014: 96). Finally, an assortment of participation tools enhances the users' sense of agency and involvement (Shifman, 2014: 96). Ide serves as a supportive example for these considerations since its content seems to be simple (in terms of being repeated), humorous, and accessible for various participation activities. Humour, simplicity, and participation facilitate circulation in the affective economy.

The humor element plays a specific role as a driver of affective energy. Ide, itself based on expression of joy and laughter, evokes the laughter of the audience. And, as we demonstrated from YouTube commentaries, the laughter of the viewers has not a common, unified character. Laughter embraces joy, pleasure, and approval, as well as is fraught with the danger of mockery and humiliation. Laughter is often considered multifaceted and even paradoxical. It is at the same time a destructive and creative source. Laughter exposes the meaninglessness and absurdity of the existing social relations and conventions of human behavior. But through destroying, it builds something of their own: "the world of disturbed relations, of nonsense, of freedom from conventions and, thus, the world to some extent desirable and carefree" (Likhachev et al., 1984: 3). According to the Russian philosopher and critic Mikhail Bakhtin (1968), laughter functions as a liberating force in the spirit of transgression. His concept of carnivalesque refers to the overcoming of boundaries through humor and chaos. Although Goriunova calls not to treat new media idiocy as a new kind of carnivalesque, since "there is not always and not even often a crystallization of the subversive through the idiotic" (2013:232), we recognize emotional expressions that do not conform to dominant cultural perceptions. 
Ide has received both widespread comment and remix online but has also garnered attention from television. In October, 2011, Goncharenko appeared on an episode of a news programme in one of the most popular channels in Russia Channel One. Ide was shown to TV audience and called a funny scene in which a retiree feels “unrestrained happiness” and expresses “truly non-human delight” (YouTube, 2011) Comment [AF6]: bibliogrpahy about a quite ordinary event - catching a fish. In the Russian context, these phrasings reflect transgrassive character of the character's laughter. The TV coverage of the video evoked controversial public reaction. On the one hand, a large part of the audience is amused by the way a man has become famous. On the other hand, many viewers consider this video not worth attention on TV:

Is there no other news in the country?! (gerihz39, YouTube, 2013).

There are also some ironic comments regarding Ide's surprising growing popularity:

Wow, this Ide is already on "Channel One", let's lobby him to become a president! (Dmitry Leps, YouTube, 2012).

What is remarkable is that the coverage of the event was made with reference to the YouTube account from which the video was taken - PenekTV, which is supposed to be one of the most popular Russian YouTube channels containing "funny and absurd videos”. These videos are used as original materials for various comedy sketch clips Comment [AF7]: citation made within Russian YouTube Poop (RYTP) genre. RYTP can be defined as a type of video mashup produced by editing pre-existing media sources and using different visual or auditory effects mainly for the purposes of humor and entertainment. RYTP is a Russian version of YouTube Poop based on the country's cultural context and having to 
do with popular Russian memes. PenekTV calls RYTP "extremely crazy remixes of different videos that might cause an objection" and, sarcastically, "by browsing RYTP content, you agree that you are mentally and physically healthy, and tolerant towards other people's desire to express themselves, no matter how strange this desire might be ...” (PenekTV, Youtube). The channel exemplifies the production of profitable digital Comment [AF8]: citation entertainment since its owner makes money through placing advertising on created poops. His activity is indicative of how some users position themselves as nodes in the affective circuitry of idiot videos.

Goncharenko has become a popular figure on Russian television. He gave an interview on the popular TV programmes "Central TV" on the channel NTV and the talk Comment [AF9]: when? show "Let It Be Said" on Channel One. He was invited as a guest to be on the comedy show "Comedy Club" on the channel TNT and appeared in one of the promotional announcements of the channel Pepper. What is more, the channel TNT used the soundtrack of the famous remake of Ide in an advertising trailer of "The Lord of the Rings” movie, humorously presenting Gollum as being excited about his "Yaaazz." One user's reaction to this popularity:

This man is genius, 30 seconds of emotional nonsense and you're in "Let It Be Said", on all sites, in "Comedy Club", and all channels: MASTERPIECE: D (TehnoboySan4o, YouTube, 2012).

What is remarkable is that on every television show where Goncharenko took part, he was asked to reproduce his passionate scream. Without question, he repeatedly demonstrated the yell (with minor variation). In every appearance, he emphasized that the emotions felt at the time of the catching of the fish of 'his dreams' were spontaneous and 
sincere. However, as can be seen from his public appearances, he was willing to cry his trademark phrase again in less inspirational contexts in order to please the audience. This, despite the fact that in our interview he pointed out that those feelings on the video are impossible to fake. But it is curious that a year after his famous fishing expedition, Goncharenko caught another big ide and recorded this event on camera, crying "Yaaaz" the similar way as on the first video. It is fair to assume that through broadcasting this new video, he is trying to amuse the public in a familiar manner and maintain a particular image of himself. As Marwick states, "lifestreamers must see themselves through the gaze of others, alerting their behavior as needed to maintain their desired selfpresentation” (Marwick: 2013: 207). In this way, Goncharenko's activities follow the neoliberal logic of managing the self. Goncharenko unintentionally became famous due to his video performance, his relative uploaded the video and it later migrated to YouTube. After inspiring remixes and parodies online, it shifted to television. In the process, its producer adapted to acquire more attention by regulating his behavior in relation to the responses from social media, music, and television. His original affectation became an economy and he an affective labourer as his video migrated and he adapted to the videos feedback loop and systematic capitalist capture.

Goncharenko exemplifies a social media user having a status of micro-celebrity that is defined by Marwick as “a state of being famous to a niche group of people” (2013: 114) as well as "a way of thinking of oneself as a celebrity” presented to an audience of fans (2013: 115). This status was a result of the affective economy itself created by the feedback loop between himself and his audience. While some micro-celebrities "shun the spotlight”, others "use micro-celebrity practices to manage their audience once they reach 
a certain level of online fame” (Marwick, 2013: 117). These practices include revealing personal information and constructing connections with the audience in order to maintain the celebrity-fan relationships. In pursuing attention and visibility, social media websites play a crucial role enabling micro-celebrities to create an online presence and sustain popularity. It is seen from Goncharenko's online activities, that primarily take place on YouTube and Vkontakte, that he practices such micro-celebrity strategies, energizing his affective economy by sharing photos and videos, and interacting with his fans. He proudly claimed himself to be 'an ordinary country man' who can "enjoy simple things”, distancing himself from show business and politics. This correlates with a Greek private citizen which is “ordinary person” or “layman.” However, Goncharenko’s online activity cannot be characterized as self-centered and self-absorbed behavior that is appropriate for the idiot of Ancient Greece. As Hands points out, while in neoliberalism all the subjects of networked communities are pushed to become self-serving, self-interested individuals, they remain “paradoxically permanently connected” (Hands 2014: 243).

The affective intensities initiated online have the capacity to move out from the social media platforms to traditional media domains. The most indicative example is the increasing number of television programmes that demonstrate and comment on popular videos taken by Internet users. We are dealing with "the migration of content and intellectual property across media forms, forcing all media producers to be aware of and collaborate with others” (Lister et al., 2009: 9). Thus, for example, television channels try to hold the audience by integrating popular Internet figures into their own broadcasting. The combination of watching television with online interactive practices constitutes a media hybridity (Maruyama et al., 2014; Andrew Chadwick, 2013). Jenkins describes 
this phenomenon in terms of "convergence culture" (2006) in which content flows across "old" and "new" media. Parallel streams of information, which reach the audience via both traditional and "new” media, heighten viewer's experience. This way, viral videos and their performers are popularized through traditional media channels. Consequently, micro-celebrity status of the performer is "enhanced and cemented through mass media appearances, which then further social media status by bringing more attention and followers” (Tufekci, 2013: 858). In this way, affective economies provide opportunities for neoliberal self-commodification that are platform agnostic.

While affective economies are platform agnostic they also have no preference for particular nodes in their feedback loop. Goncharenko was invited to give a prize to the famous Russian singer Dima Bilan at "The Golden Gramophone Award”, a yearly national Russian music award ceremony. The singer was offended by the fact that he received an award statuette from the hands of "an ordinary retiree from the province" (YouTube, 2011). The emotional discussions after the ceremony were followed by the wider impassioned debates both online and offline. In particular, the incident was discussed on the television show "The Last Word”, where Goncharenko was a guest. Crucially, the celebrities who supported Bilan pointed out that it was insulting for the artist to get a national award from a person who "has become popular due to [an] absolutely idiotic video clip on the Internet” (YouTube, 2012). The affective intensities Comment [AF11]: cite of Ide created a controversy that transected the award ceremony and television. If there was a narrative, it was out of the control of Goncharenko and making its own storyline as it traveled across platforms, awards ceremonies, and talk shows, instigating parodies, remixes, and class-based controversy. 
But the affective economy retained a fidelity to its core node, Goncharenko, who, in neoliberal fashion, acquired the skill to exploit his position as micro-celebrity in the network. At the viral peak, Goncharenko turned into a professional presenter of a television cooking show launched in March 2012 on the channel Russia-2. The nickname "Yaz," firmly established for him online, is his stage name. The first project of this show implies a competition between Goncharenko and popular Moscow chefs. The second project is devoted to Russian local and ethnic cuisine. In the second season, he visited other countries in order to try and cook the most exotic food. In an interview, Goncharenko mentioned that he wanted "to go abroad and see the world, to show himself, to be in demand and bring people joy” (YouTube, 2013). His capacity to quickly learn to comport himself as a micro-celebrity in neoliberal fashion has made his dream a reality. His accidental video, of affective intensities circulated in a feedback loop across multiple platforms, generated an affective economy exploited by perceptive individuals including Goncharenko himself.

\section{Conclusion}

This case study exemplifies how the exposure of an entertaining event in a particular online community has led to popularity in digital and traditional media and resulted in an attractive television job. This is what neoliberal ideology teaches Internet users: broadcast and exploit yourself. It is in this self-commodification of the most inane and passionate acts that neoliberal subjectivity and networked idiots meet. This "idiocy" is produced through users' participation that is "not summed up by one or two clicks, but is compositional, conceptual and performative itself" (Goriunova, 2013: 230-231). Such 
participation is itself beneficial for the members of the network who pursue personal goals varying from pleasure and communication to self-advertising and financial profit.

This economy of idiot videos is reliant upon the capture and circulation of affect. While neoliberal theory argues that individuals need to self-regulate, affectual economies exploit the risky “venture labor” of precarious microcelebrities (Neff, 2012). Goncharenko eventually learns to comport himself in neoliberal fashion to continue his micro-celebrity ascent to television and beyond. But the declaration that started his saga, infecting a network with affectual reverberations, was anything but an exhibition of selfmanagement. Neoliberalism explains the adaptation of subjectivity but as an economic theory cannot explain origin events nor the virality of affect. Political economic theories of neoliberal structuration need to be complemented with cultural theories of participatory culture and agency (Author, 2014).

As the brief history of Ide illustrates, the video and its hydra heads circulated through a number of “digital entwined feedback loops” consisting of internet platforms, remixes, parodies, television networks, as well as the bodies and speech acts of various interlocutors. During the period of its virality, its producer learned to lifestream and he developed the neoliberal subjectivity of a microcelebrity that enabled him to manage and exploit his position as a central node in an affective economy. Others too capitalized on the attention the video produced in order to position themselves as nodes in the video's feedback loop. In this way, the affective economy gave way to affective labor as people gave time and energy in order to capture capital produced through circulation. 


\section{REFERENCES}

Ahmed, S. (2004a). ‘Affective Economies’, Social Text 22 (2): 117-139.

Ahmed, S. (2004b). Cultural Politics of Emotions, Edinburgh: Edinburgh University Press.

Bakhtin, Mikhail (1941). Rabelais and his world. Bloomington: Indiana University Press.

Bakhtin, M. M. (1984 [1965/1968]). Rabelais and his World. Trans. Hélène Iswolsky. Bloomington: Indiana University Press.

Benkler, Y. (2006). The Wealth of Networks: How Social Production Transforms Markets and Freedom. New Haven, CT: Yale University Press.

Berry, D.M. (2014). On Capture. http://stunlaw.blogspot.co.uk/2014/04/oncapture.html [accessed 23.01.15]

Chadwick, A. (2013). The Hybrid Media System: Politics and Power (Oxford University Press).

Chow, R. (2012). Entanglements, or Transmedial Thinking about Capture. Durham and London: Duke University Press. 
Clough, P. T. (2007). 'Introduction', in Clough, P.T and Halley, J. (eds.) The Affective Turn: Theorizing the Social. Durham and London: Duke University Press: pp. $1-33$.

Curtis, N. M. (2013). Idiotism: Capitalism and the Privatisation of Life. London: Pluto Press.

Dean, J. (2002). Publicity’s Secret. Ithaca, NY: Cornell University Press.

Deleuze G. (2008). Difference and Repetition. New York: Continuum.

Deleuze, G. (1972). 'How Do We Recognize Structuralism?' Trans. Melissa McMahon and Charles J. Stivale. In Desert Islands and Other Texts, 1953-1974. Ed. David Lapoujade. New York: Semiotext(e), 2004. ISBN 1-58435-018-0. 170-192.

Deleuze, G. and Guattari, F. (1994), What is Philosophy? trans. H. Tomlinson and G. Burchell, New York: Columbia University Press

Dostoevsky, F. (1869) The Idiot. Translated by Eva Martin (1915).

Eshelman, K. (2012). The Social World of Intellectuals in the Roman Empire. Cambridge: Cambridge University Press.

Featherstone, M. (2010). 'Body, Image and Affect in Consumer Culture,' Body \& Society 16(1): 193-221.

Author 2014

Author and RM 2012

Foucault, M. (1988). Technologies of the self. In L. H. Martin, H. Gutman and P. H. 
Goffman, E. (1955). 'On Face-work: An Analysis of Ritual Elements of Social Interaction', Psychiatry: Journal for the Study of Interpersonal Processes, 18(3), 213231.

Goriunova, O. (2013). 'New Media Idiocy', Convergence: The International Journal of Research into New Media Technologies, 19(2): 223-235.

Gessen, M. (2014). Words will Break Cement: The Passion of Pussy Riot. Riverhead Trade.

Gregg, M. and Seigworth, G. J. (2010). 'An Inventory of Shimmers', in The Affect Theory Reader. Durham, NC: Duke University Press: pp. 1-25.

Hansen, M.B.N. (2004). New Philosophy for New Media. Cambridge, MA: MIT Press.

Hardt, M. and Negri, A. (2000). Empire. Cambridge, MA: Harvard University Press.

Hillis, K. (2009). Online a Lot of the Time: Ritual, Fetish, Sign, Durham and London: Duke University Press.

Hofstadter, D. (2000). Godel, Escher, Bach: An eternal golden braid. London, England: Penguin.

Horeck, T. \& Kendall, T. (2014). 'Idiot Media: The Culture of NekNomination Videos', http://mediacommons.futureofthebook.org/imr/2014/04/02/idiot-media-cultureneknomination-videos [assessed 23.01.2015]

Hutton (eds) (1988). Technologies of the self. Amherst: University of Massachusetts Press, pp 16-49. 
Izvestia (2012) 'Fisherman and ladle’: http://izvestia.ru/news/523596 [assessed 20.08.2014]

Jenkins, H. (2006). Convergence Culture: Where Old and New Media Collide. New York: New York University Press.

Joss Hands (2014). ‘General Intellect or Collective Idiocy? Digital Mobs and

Social Media Mobilization', Popular Communication: The International Journal of Media and Culture, 12:4, 237-250

Kuntsman, A. (2012). 'Introduction: Affective Fabrics of Digital Cultures', in Karatzogianni, A. and Kuntsman, A. (eds.) Digital cultures and the politics of emotion: Feelings, affect and technological change. Basingstoke: Palgrave Macmillan, pp. 1-17.

Lazzarato, M. (2007). 'Machines to Crystallize Time: Bergson', Special Issue on Life and the New Vitalism, Theory, Culture \& Society 24(6): 93-122.

Lister, M., Dovey, J., Giddings, S., Grant, I., and Kelly, K. (2009). New Media: A Critical Introduction (2nd ed). London and New York: Routledge.

Likhachev D. S., Panchenko A. M., Ponyrko N. V. (1984). Smekh v drevnei Rusi [Laugh in Ancient Russia]. Leningrad, Nauka.

Lovink, G. (2011). Networks Without a Cause: A critique of Social Media, Cambridge, Polity Press.

Maruyama M., Robertson S.P., Douglas S., Semaan B., Faucett H. (2014). 'Hybrid Media Consumption: How Tweeting during a Televised Political Debate Influences the Vote Decision', Proceedings of the $17^{\text {th }}$ ACM Conference on Computer Supported Cooperative Work, 
http://www2.hawaii.edu/ bsemaan/maruyama_mediahybridity_cscw2014.pdf [accessed 23.01.15]

Marwick, A. (2013). Status Update: Celebrity, Publicity, and Branding in the Social Media Age. New Haven and London: Yale University Press.

Neff, G. (2012). Venture Labor: Work and the Burden of Risk in Innovative Industries. Cambridge: MIT Press.

Ober, J. (1991). Mass and Elite in Democratic Athens: Rhetoric, Ideology, and the Power of the People. New Haven, CT.: Princeton Press.

Papacharissi, Z. (2015). Affective Publics: Sentiment, Technology, and Politics. Oxford: Oxford University Press.

Papacharissi, Z. (2010). The Private Sphere. London: Polity Press

Raun, T. (2012). 'DIY Therapy: Exploring Affective Self-Representations in Trans Video Blogs on YouTube’, in Karatzogianni, A. and Kuntsman, A. (eds.) Digital cultures and the politics of emotion: Feelings, affect and technological change. Basingstoke: Palgrave Macmillan, pp. 165-180.

Reestorff, C. (2014). Mediatised Affective Activism. The Activist Imaginary and the Topless Body in the Femen Movement. Convergence, 20(4): 478-495.

Rheingold, H. (2002). Smart mobs. New York, NY: Basic Books.

Shifman, L. (2014). Memes in Digital Culture. Cambridge, MA: MIT Press.

Shirky, C. (2010). Cognitive surplus. London, England: Allen Lane.

Surowiecki, J. (2004). The wisdom of crowds. London, England: Abacus. 
Tufecki, Z. (2013). “Not This One”: Social Movements, the Attention Economy, and Microcelebrity Networked Activism, American Behavioral Scientist, 57(7): 848 870.

Volna.afisha.ru (2011), 'Final results - 2011’ http://volna.afisha.ru/archive/itogi-2011by-critics/ [assessed 20.08.2014]

Williams, R. (1977)

Comment [AF13]: Finish

YouTube (2011) 'Ide - the fish of my dream! | Source', by PenekTV http://www.youtube.com/watch?v=TY1ymotP0P0 [assessed 20.08.2014]

YouTube (2011) PenekTV: http://www.youtube.com/user/PenekTV/about [assessed 20.08.2014]

YouTube (2011) 'This is horosho [YAAAAAZ!]', by This is Horosho: http://www.youtube.com/watch?v=Ztv-vjhNl9A [assessed 20.08.2014]

YouTube (2011) 'Diet Coke and Mentos Human Experiment **DON'T TRY THIS AT HOME** | Furious Pete', by Furious Pete: http://www.youtube.com/watch?v=K6xXngYnVK8 [assessed 20.08.2014]

YouTube (2012) 'The Cinnamon Challenge ... by GloZell and her Big Behind Earrings', by GloZell Green: http://www.youtube.com/watch?v=Cyk7utV_D2I [assessed 20.08.2014]

YouTube (2012) 'Milking Newcastle', by MilkingNewcastle: http://www.youtube.com/watch?v=qtJPAv1UiAE [assessed 20.08.2014]

YouTube (2014) 'Ronald McDonald's EXTREME NEKNOMINATE!!', by RackaRacka: http://www.youtube.com/watch?v=LRX5MiOG420 [assessed 20.08.2014] 
YouTube

'IdiotikShow',

https://www.youtube.com/user/IdiotikShow/about [assessed 20.08.2014]

YouTube (2011) 'Yazz!!! Ide! Parody', by GenkaPaltus:

http://www.youtube.com/watch?v=OQAmoge1UwA [assessed 20.08.2014]

YouTube (2011) 'The son of Ide Yaz!!!' by Podpishis i mir stanet lutche: http://www.youtube.com/watch?v=0oCMxqhXkoY [assessed 20.08.2014]

YouTube (2011) ‘Arnold Schwarzenegger- Ide’, by_MineralkaHD http://www.youtube.com/watch?v=1jlI3g-cLFM [assessed 20.08.2014]

YouTube (2011) 'Yaaaaz', just backward', by turikhayable http://www.youtube.com/watch?v=3BxIBOEzBIE [assessed 20.08.2014]

YouTube (2012) 'Ide!!! Hard Dubstep!!!’, by ZeLo MC http://www.youtube.com/watch?v=bFVh4OZRaU8 [assessed 20.08.2014]

YouTube (2009) 'Mr. Trololo original upload', by_RealPapaPit: http://www.youtube.com/watch?v=oavMtUWDBTM [assessed 20.08.2014]

YouTube (2011) 'Lord Of The Rings Yaz!!', by bodry : http://www.youtube.com/watch?v=pUaOGexx154 [assessed 20.08.2014]

YouTube (2011), 'Ide on the Channel One', by PenekTV: http://www.youtube.com/watch?v=B0UIJpcj6D8 [assessed 20.08.2014]

YouTube (2013) 'Interview with Ide. It needs to believe in miracles', by Agnia Ogonek: http://www.youtube.com/watch?v=GVVIpgtOlao [assessed 20.08.2014]

YouTube (2012) 'Ide NTV The last word original', by Jack Budvar: http://www.youtube.com/watch?v=ocqeN6KiL8c [assessed 20.08.2014] 
YouTube (2011), 'Scandal !!! Ide and Dima Bilan. The Golden Gramophone Award', by $\quad$ Viktor $\quad$ Goncharenko $\quad$ YouTube: http://www.youtube.com/watch?v=j3rlfHpckVI [assessed 20.08.2014] 